\title{
LHUILLERY, Stéphane \\ Organisation and location of academic sourcing at the firm level
}

\author{
Ecole Polytechnique Fédérale de Lausanne, \\ Chaire en Economie et Management de I'Innovation, \\ stephane.Ihuillery@epfl.ch \\ May 2005 CEMI-REPORT-2005-001
}

Article publié dans... / Article à publier dans ...

Keywords : R\&D, geographic spillovers, universities, absorption

JEL classification : $\mathrm{O} 32, \mathrm{R} 32, \mathrm{~L} 60, \mathrm{C} 34$

\begin{abstract}
Thanks to the second French Community Innovation Survey, a measurement of the importance of public research organisations as a useful source of innovation for manufacturing firms is available. We thus provide an exploratory econometric model where the internal R\&D organisation and location of business units at the city level are both considered as explaining factors for the absorptive capacity dedicated to academic knowledge. Size, R\&D intensity and organisation are found to be significant determinants of academic sourcing. The influence of local public research organisations on innovation is however found rather small and not restricted to urban areas.
\end{abstract}




\section{Table of content}

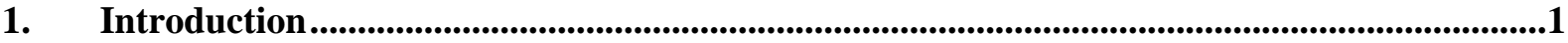

2. Academic sourcing: theoretical and empirical background .........................................................2

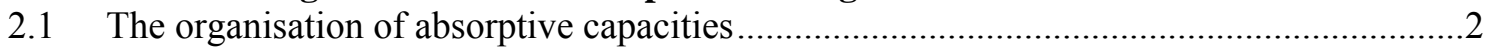

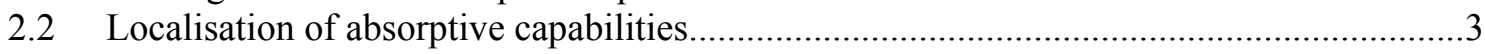

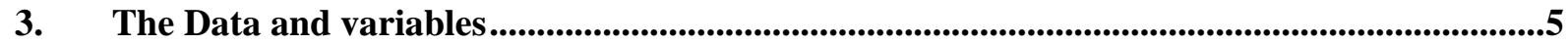

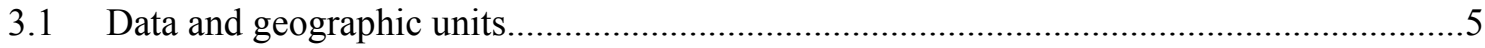

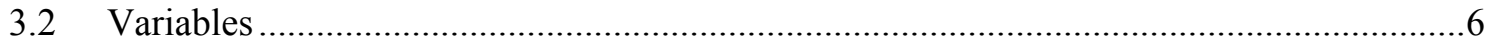

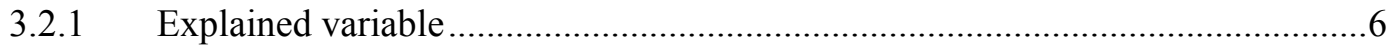

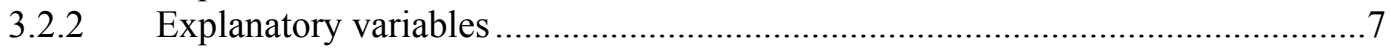

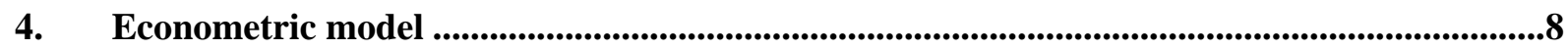

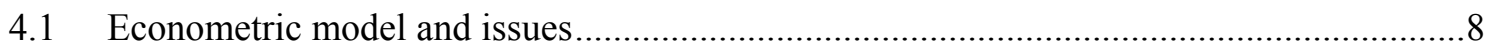

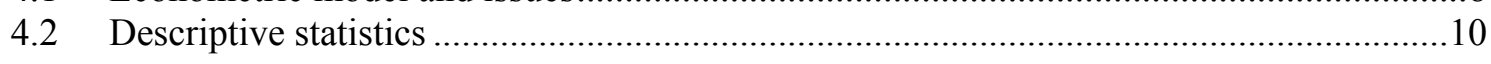

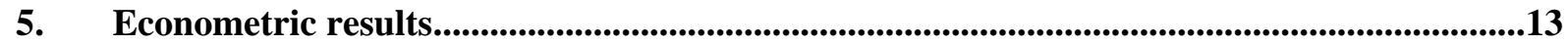

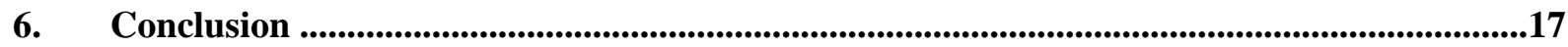

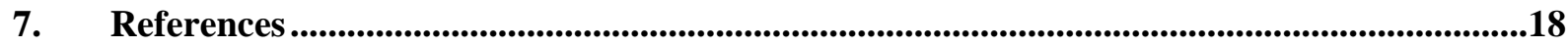




\section{INTRODUCTION}

In a breakthrough paper, Cohen and Levinthal (1989) depart from the standard view that spillovers are easily and freely acquired. The recipient firm must invest into absorptive capacities in order to be able to use external knowledge within the innovation process. In the paper, Cohen \& Levinthal also underlined that the necessary investment cover many possible means and channels as many empirical works now reveal: the academic sourcing by firms relies on different external strategies allowing connectedness such as co-publishing (Cockburn and Henderson, 1998), coming closer to leading scientists (Zucker et al., 1998), cooperating with public labs faculty, recruiting graduate students, participating in research consortia ( $\mathrm{Lim}, 2000)$. On a sample of 1,478 US R\&D lab managers in the manufacturing sector., Cohen et al. (2002) show however that connectedness is maybe more informal than suggested by previous works : publications, conferences, informal interactions seems to be more important than market mediated channels (licenses, contract research, consulting...) even if many are implemented at the same time.

Internal organisational factors, constituting the prerequisite for such external absorptive activities, have however attracted much less interest among scholars. Internal R\&D investments remain the main internal absorptive capacity factor considered. The purpose of this paper is to extend the internal absorptive framework focusing on strategies dedicated to academic knowledge sourcing implementing an alternative econometric methodology including location strategies. Size of firms, as well as the structure and organisation of their internal industrial R\&D activities are considered as possible enhancing factors of academic sourcing. On a sample of innovative firms (CIS2), we confirm that large firms and firms with higher R\&D intensity are better recipients of academic knowledge. A third finding is that higher intensity of basic and applied research in R\&D internal expenditures induces higher academic sourcing efficiency. Fourth, specialisation of knowledge activities within a in-house $R \& D$ centre is also found to be a significant means of learning about public research organisations. Fifth, native groups are more likely to learn from their local or regional public research organisation than independent firms. Foreign groups seem to be also less effective at direct tapping academic knowledge.

Other authors in economic literature suggest that knowledge spillovers tend to be geographically bounded within the region where the new economic knowledge was created. A bulk of empirical results on U.S. data is backed by vivid works in geographic economics supporting the central role of cities in learning (See Glaezer, 1999; Fujita \& Thisse, 2002). The literature deals especially with the influence of universities on firms and agglomeration effects are often found positive. If so, localisation becomes a factor of absorptive capacity for firms. If we assume that the localisation of business units and R\&D investments is endogenous, a firm is obtaining academic knowledge thanks to an absorptive capacity built at the city level through the settlement of its different business units. The local R\&D investment is considered as well as non-R\&D activities as a potential source of absorptive capacities. We thus explore the effects of $R \& D$ and non-R\&D absorptive capacities dedicated to local (city) and nearby (regional) academic knowledge. Five broad additional conclusions are reached in the paper: larger academic research surrounding firms increases its ability to benefit from their results. Within a

same firm, business units with R\&D units are more able to learn from their academic environment than plants without R\&D. A further point is that firms are more likely to be innovators if their business 
units are settled in cities or regions with important public research organisations. There is little evidence that geographic distance bounds learning within cities; our results suggest that the regional level of academic knowledge may be as important as the city level. Last, the impact of the location close to public research organisations seems rather small compared to other strategies.

The rest of the paper proceeds as follows: in Section 2, we introduce the main issues concerning the determinants of absorptive capacities as well as the methodological difficulties to deal with local academic knowledge that we will address in the paper. After the data and variables are presented in section 3 with descriptive statistics, the empirical hypotheses, the econometric specification and issues are provided in Section 4. Section 5 reports regression findings on the probability to be an innovator, as well as on the efficiency of academic sourcing. Section 6 concludes.

\section{ACADEMIC SOURCING: THEORETICAL AND EMPIRICAL BACKGROUND}

\subsection{The organisation of absorptive capacities}

Four standard arguments are put forward when absorptive capacity is considered. A first one suggests that large firms may differ from smaller firms in their ability to cope with external knowledge. SMEs would be better explorators of new technological fields (Acs and Audretsch, 1990; Saxenian, 1994 ; Almeida and Kogut, 1997). Empirical findings rely on restricted samples or industries but they are puzzling if one think about SMEs as poor R\&D investors or with weaker human capabilities. The overall argument deals with the necessary knowledge out-sourcing in front of their internal lack of knowledge production. Beyond the substitutability argument, SMEs are assumed to be more efficient in informal learning activities that are believed at the core of knowledge sourcing. In a recent paper, Adams (2001) uses a survey of industrial 600 U.S. R\&D laboratories owned by 200 firms. Explaining a direct quantitative measure of academic learning expenditures, he finds however a positive and significant effect of size. The result is also corroborated by Cohen et al. (2002). The authors suggest that the effect of public research on industrial innovation process is much greater for large firms. The relation is however found higher for start-ups suggesting that the $U$ shape relation suggested for industry sourcing would be more pronounced for academic tapping.

The ability to benefit from external stocks of knowledge depends also on the level of R\&D (See Jaffe 1986; Henderson \& Cockburn 1996; Adams \& Jaffe, 1996). On a large sample, Cohen \& Levinthal (1989) show that firms must invest in R\&D in order to absorb knowledge spillovers especially when academic knowledge is targeted. Performing R\&D may increase a firm's ability to identify and select technological external opportunities, and to shift them into innovation (Arora \& Gambardella, 1994).

The $R \& D$ framework remains however broad and hardly separates the learning side from the knowledge production side.

A third precision on absorptive capacity is thus often made in the empirical and theoretical literature. Several authors suggest that the absorptive capability relies on basic or upstream research rather than applied research or development (Rosenberg, 1990; Pavitt 1991; Cockburn \& Henderson, 1998 ; Cassiman et al., 2002). As Cohen \& Levinthal (1989) first suggested : "Specifically firms may conduct basic research less for popular results than to be able to identify and exploit potentially useful scientific and technological knowledge generated by universities or government laboratories, and 
thereby gain a first mover advantage in exploiting new technologies » (p. 593). However, there is still no empirical results on large samples corroborating such a stylised fact even if it appears in theoretical works (See Adams, 2001; Cassiman et al., 2002). Several empirical evidences on academic publications by private researchers and co-authoring between industrial and academic researchers give serious clues about such behaviour. Several detailed case studies show however that there is industries where applied research and academic standards do not fit (See Vincenti, 1991; Lim, 2001). The possible differences are even implicitly recognised by Cockburn et al. (1999), through the need of two complementary incentive practices toward $R \& D$ staffs within a same firm (patenting vs. publishing individual incentives). The divorce will be considered below with works based on patents.

An organisational fourth dimension in the absorptive capacities of firms dealing with industrial or academic knowledge can be introduced. In house laboratory can be considered as more efficient thanks to a specialisation in knowledge production as a learning by learning process (Stiglitz, 1987; Le Bas \& Zuscovitch, 1993). The important organisational issue received however little empirical supports thank to the scarcity of data. On a sample of about 290 Flemish companies with R\&D, Veugelers (1998) suggests that having its own in-house R\&D department induces a larger positive effect of co-operation on internal R\&D. Focusing on academic sourcing, Adams (2001) does not find however a significant positive effect of an in-house laboratory on learning capacities.

Last, the ability to absorb academic knowledge may be different for affiliates of multinationals enterprises. More and more MNCs are tapping into local resources and weave links with indigenous technology sources (See Niosi, 1999; Von Zedtwitz \& Gassmann, 2002). MNCs establish R\&D facilities to tap into industrial knowledge as well as into academic knowledge (Granstrand et al., 1993). Cultural distance is also found to be an hampering factor of such strategy (Håkanson, 1993).

\subsection{Localisation of absorptive capabilities}

Localisation can be considered as a sixth type of arguments in absorptive capacity building. The main argument is that knowledge spillovers are geographically-bounded. If the hypothesis is true, localised knowledge spillovers would be a cause of local settlement for firms. Firms should settle close to industrial R\&D investors or universities to benefit from their knowledge production or, if not, they might invest more on travelling and communication to compensate their isolated location. Even if a shift of localisation includes important adjustment costs, we can consider that localisation is endogenous to the firm (As suggested by Zucker et al., 1998). Local knowledge spillovers are one of the several dimensions taken into account (as labour market, fiscal incentives and taxes, social and cultural environment...) when such a decision is taken. The localisation literature deals with local knowledge inputs where industrial and academic sources are usually separated. Since different surveys are already available dealing with methodologies and results (Feldman, 1998; Breschi \& Lissoni, 2001), we present here a partial view of difficulties in the field.

Mainly two methods are used to estimate the role of knowledge externalities at different geographical distances. A first method uses a knowledge production function ${ }^{1}$. The method fell under usual

After Jaffe (1989), the externality problem is usually considered through a knowledge production function that relates an output measure K for "knowledge" to two input measures: research and development performed by industry (IR\&D), and research performed by universities $(\mathrm{U})$ as: $\log (\mathrm{K})=\alpha+\beta \log (\mathrm{IR \& D})+\gamma \log (\mathrm{U})+\lambda \log (\mathrm{Z})+\varepsilon$, where $K$ is 
criticisms on patents when the indicator is used as the output variable (See Griliches for a survey, 1990). A second strain of research ${ }^{2}$ deals with patent quotations in publications as a direct measurement of the impact of knowledge sourcing. Relying on patents, the method is unfortunately bounded with the same problems and cannot measure the supply of academic knowledge. As Agrawal and Henderson (2002) reveal, patents account for less than $10 \%$ of the knowledge transfers from public research organisations. Furthermore, quotations of academic publications, or even co-authoring analysis, may be also here misleading since more applied public laboratories can be more effective at transmitting knowledge and worst on a publication criterion. As found by Mansfield $(1995,1996)$, proximity between universities and industries may matter more for applied research than fundamental research. There is indeed no simple link between high academic standards measured by patents or patent quotations and high opportunities for firms that are partly embedded in their national system of innovation where technology transfers can be managed by non-academic gatekeepers (see Beise \& Stahl, 1999, on the German case). Such restriction is thus to be relaxed even if it may still hold in biotechnology (See Audretsch \& Stephan, 1996; Zucker et al., 1998).

Another traditional criticism toward work on externalities is also that there is no attention paid to the different mechanisms implemented to transfer knowledge that remain unknown (Jaffe et al., 1993; Breschi \& Lissoni, 2001). Since such routines and artefacts are hardly identified, there are always serious doubts on the significance of correlation between firms' stocks of knowledge and especially between academic activities and industrial innovation production. Furthermore, the use of administrative or circular geographic areas gives little rationale for real geographic interactions. Even if we are not able to take the different channels into account, we can assume that urban areas are a facilitating factor for knowledge diffusion through a higher probability of learning and a higher probability of meeting academics (Glaeser, 1999).

Apart from patent and bibliometric methods, a better indicator is the number of innovations per business. However the quality of an innovation is hard to assess and only product innovations are considered (Audretsch et al., 1999). The output indicator is also puzzling when used at the geographic level if the purpose is still to understand the impact on innovation of academic knowledge: Audretsch et al. (1999) underline that innovation is counted at the business unit level that is responsible for the majority of the work leading to the innovation. In fact, there is an implicit assumption that academic sourcing is linked to the business unit that is considered at the core of the innovative process placed at the firm level. Several empirical studies present however a broader view of innovation : in a former study, Feldman (1994) suggests that academic proximity matters for R\&D activities rather than innovation process; collective interactions between business units within firms are found as critical for innovation achievement (see Kusunoki et al., 1998; Hansen, 1999). Innovation process within a firm can thus be considered as an integration process where inventions or parts of new knowledge can be produced or absorbed at the local level. Weak participants can even be critical in the intra-firm collective process (Hansen, 1999). Local business units, involved in academic sourcing, can often be considered as weak ties dealing with only restricted parts of the innovation, and not counted as the main innovator.

approximated by patents, innovation counts ( $\varepsilon$ as a stochastic error term and $\mathrm{Z}$ is the other set of explanatory variables). The production function is usually estimated at an aggregated geographic level. See however Adams (2001) for a method using individual data.

2 See the seminal article Jaffe, Trajtenberg et Henderson (1993). 
Last, studies based on the spatial aggregation of data often omit local units with no public research organisations or non-innovative areas where public labs are settled. The selection has to be considered at least because non-innovative firms can also be influenced by academic sourcing ${ }^{3}$.

Thanks to this short subjective summary, five difficulties are thus to be addressed in the next sections: Innovation is considered at the firm level and not at the business unit level; similarly, the local absorptive capacities effectiveness is measured at the firm level rather than at the business unit level. A proxy of real academic sourcing is used to escape the usual causality trap. Selection effects are to be taken care for non-innovators. Last, the geographic units considered are small and reflect more likely possible local interactions between academic and industrial employees. Besides, less demanding variables such as size, $R \& D$ intensity, upstream research or the number of in house $R \& D$ centre are also introduced when absorptive capacities are dealt with.

\section{THE DATA AND VARIABLES}

\subsection{Data and geographic units}

Our contribution combines four separate surveys: the French CIS2 survey, the annual firm survey, the annual R\&D survey, the Telelab survey. The well-known CIS2 survey deals with the sources of technological innovation on a sample of manufacturing firms with more than 19 employees. The sample period is 1994-1996. We use the data available in the other data sets to complete the information available at the firm level with information at the business unit level. It is easy to track the localisation of the different establishments for the different firms thanks to the mandatory annual business survey (Enquête annuelle des Entreprises) carried out by the Ministry of Industry (SESSI). This data set provides information on location thanks to the ZIP code and name of cities of the business unit. The annual survey was used at the business unit level to locate the different business units of firms that were active from 1993 to 1996.

Regarding the assessment of $R \& D$ activities, the mandatory $R \& D$ annual survey from the Ministry of research and Ministry of higher education (DPD C3) was used for the 1993-1996 period. Until 1998, an introductory question gave ZIP codes and name of cities where business units with an R\&D activity are implemented. We are however not able to know the level of $R \& D$ expenditures or the number of researchers at the local level even if additional information are available on the R\&D process at the firm level.

Public research activity is also measured for the 1993-1996 thanks to the Telelab data set (Ministry of research), which was available until 1998 at the ministry of research. The data set was based on an annual survey of each of the French public laboratories. The Telelab gathered more than 6000 public laboratories with its identity (name, head), numbers and type of employees, its geographic localisation (ZIP code and city), and academic fields.

Combining the three data sets, we are able to locate the activity of a firm through it different plants, telling if an R\&D investment is done within the geographic area where the firm is settled and if public

3 Similarly, non-R\&D firms can also benefit from academic knowledge. 
researchers are working in the same area. Thanks to zip codes and names of cities, several geographic definitions can thus be defined as regions or departments. Smaller areas such as "Employment areas" can be defined on the daily observation of workers or "urbanised units" (Unités urbaines) based on the continuity of buildings. 2153 urban units were defined covering the French territory including isolated cities, rural areas ${ }^{4}$ and Corsica. In our paper, the basic sustained geographic area is the "urban unit". However, the Paris urban unit is still very large and covers almost the entire region. We decide to divide Paris urbanised unit into 21 different "employment areas". Business units or plants are thus dispersed among 2173 geographic zones $(u=1, . ., 2173)^{5}$. A second wider geographic area $r$ represents the surrounding urban and non-urban areas included within a region $(r=1, . ., 22)$. The sustained geographical unit $\mathrm{u}$ does not fit the administrative area that is the departments in France but is included within the higher administrative regional area.

Within the CIS2 sample, $82 \mathrm{R} \& \mathrm{D}$ firms declare to be non-innovators and are deleted ${ }^{6}$. Firms that spend more than $50 \%$ of their turnover in R\&D are not considered to be manufacturing firms and are therefore also deleted from the sample. 4066 manufacturing firms owning 15932 different business units are in our final sample where 2339 firms are innovators.

\subsection{Variables}

\subsubsection{Explained variable}

The CIS2 questionnaire gives a measurement of each firm and each kind of knowledge sources. It does not give a measure of the bulk of knowledge available from the academic world but the effectiveness of its absorption and use for technological innovation. We defined the "academic knowledge impact" (AKI) as our explained variable. The place of academic sourcing is evaluated by each firm on a four degree Likert scale $(0: \text { null, } 1: \text { weak, } 2: \text { moderate, } 3: \text { strong })^{7}$. The variable is defined at the firm level and not at the establishment level. A geographically dispersed firm's absorptive capacity is thus related to the available stock of academic knowledge in the regions where the firm is present. The variable deals with academic sourcing of innovation rather than with invention sourcing; it also takes into account the fact that the absorptive capacity of academic knowledge is organised endogenously by firms i.e. it combines knowledge produced or absorbed by the establishments of a firm which do not know or control the impact of this knowledge on the innovating process of the firm as a whole.

4 Rural areas are the geographic zones within a department that do not include neither cities, nor suburbs, nor isolated cities.

5 An alternative definition would be the "urban zone" definition based on the daily flows of employees. The number of "urban zones" is 354 that is much less than the chosen urban units but closer to the definition of US metropolitan statistical area (MSA) that are used in several U.S. papers.

6 More than $60 \%$ do not even declare any obstacle and can thus be considered as non satisfying respondents to CIS2.

7 The question was: «What were the main sources of information for innovation between 1994 and 1996 (to initiate new projects or contribute to existing projects) ? Proposed items were mainly: internal sources, other firms within your group, competitors, customers, equipment suppliers, material suppliers, consulting firms, universities or other higher education organizations ; public research organizations (CNRS, INRIA, INSERM...) or non profit organisations. 


\subsubsection{Explanatory variables}

Turning to the definitions of the right-hand-side variables, we first introduced variables as the localised stocks of S\&T knowledge produced by public research organisations. We thus deal with other control variables.

First, the stock of academic knowledge is computed at the urban unit level depending on the activities within the urban area in $1993^{\circ}$ : We used here the only available variable that is the number of researchers or assimilated added to $\mathrm{PhD}$ students and invited faculties.

$K_{U}^{i}$ is thus defined as the potential academic knowledge available through the local economic activity within the different French sustained geographical units $u$. The stock of academic knowledge at the urban unit level can be separated into two bulks of knowledge: $K_{U}^{i, P R O D}$ is defined as the stock of academic knowledge in all academic fields $(j=1, . ., 31)$, available by urban areas where firm $i$ has only non-R\&D activities; similarly $K_{U}^{i, R D}$, the stock of academic knowledge available trough urban areas where firm i carries out R\&D (see Appendix A.).

The influence of public research, even important at the urban level, may exist at the regional level. In order to test the impact of this second knowledge belt on firms, the stock of academic knowledge $K_{R}^{i}$ can also be computed at the regional level (NUTS2) as the sum of academic knowledge at the regional level minus the possible sum of knowledge computed at the urban unit level (see Appendix A.). The stock at the regional level can include academic stocks of knowledge that belong to urban areas where a firm has non-R\&D activities, $K_{R}^{i, P R O D}$; similarly, $K_{R}^{i, R D}$ is the stock of academic knowledge available through the non-urban areas within a region where firm $i$ carries out $R \& D$.

For tractability reasons, we do not distinguish the different types of R\&D staffs, nor the different types of public research organisation (mainly university labs versus other public research organisations). The definition of variables relies on the assumption that the number of employees in the organisation approximates the stock of academic knowledge produced in a laboratory. The use of lab employment as a proxy for knowledge production is thus based on the assumption that the global productivity of public labs remains constant as well as the capital/labour ratio. Of course, one clear additional shortcoming of the exercise is that we are not able to take into account foreign academic research as Arundel and Geuna (2001) do and despite rocketing foreign R\&D investment by French innovating firms. Lastly, as the definition shows, we do not pay any attention to the repartition of academics among the different kinds of knowledge in the several scientific and engineering fields. In a further research, we should deal with the importance of separating effects of the different fields of knowledge.

Second, control variables are included in our empirical model: SIZE (log number of employees) is introduced. Dealing with academic knowledge, we expect, however, bigger firms to have a higher probability to connect with academic researcher. The U shape found by Cohen et al. (2002) seems however hard to test since there is no start-up companies in our sample. Nevertheless we pay attention to the hypothesis testing if it may hold for small firms. The relative effort of R\&D, R\&D INT is measured by the average R\&D intensity on the 1993-1996 period, at the firm level, is also expected to

Even if we introduce a one year lag between the academic stock and the period of observation of the innovation process (1994-1996); the lag does not reflect the pace of academic sourcing that seems to be much slower as shown by Adams (1990) and Mansfield (1991) 
be positive and significantly correlated to the ability to access and to develop academic knowledge. R\&D intensive firms might also be more likely to go abroad for academic knowledge (Arundel \& Geuna, 2001). We expect that the introduction of the variable would mitigate the bias induced by a lack of data regarding foreign stock of academic knowledge. The group dimension is available through two additional variables: FRGROUP and FORGROUP are respectively dummies that are 1 for firms belonging to a French and foreign group (With at least $50 \%$ of shares). Residual firms are independent (INDEP $=1,0$ otherwise) .

Two additional variables are available here at the firm level: Since the level of fundamental research is not a very sharp indicator in R\&D surveys, we rather compute, SBAR, the share of basic and applied research in the R\&D budgets (on average on the 1993-1996 period). Similarly, a dedicated R\&D center is a means to specialise into knowledge production and absorption and should have a positive impact on absorptive capacities. We thus define an additional variable R\&D Center that is 1 when a R\&D firm runs such a center, 0 otherwise. A boundary of the variable is that we do not know where the R\&D centers are located and the effect of such absorptive capacity can already be taken into account with the stock of academic knowledge available through R\&D.

One could argue that the proximity effect should vary with firm's R\&D intensity: R\&D intense firms are more likely to emancipated from their local resources, picking the knowledge they need all over the world. Within-industry determinants of academic knowledge impact, are considered through industry-fixed effects defined at the 2-digit level of the NACE. The intercept is substituted to a set of 14 dummies noted $\mathbf{I D}_{\mathbf{m}}(\mathrm{m}=1, . ., 14)$ which are introduced as independent variables. Each industry because of its technology, appropriation regime and size of their market (Cassiman et al., 2002), dedicated S\&T institutions (e.g. INRA for agriculture and food industry; INSERM and PASTEUR for pharmaceuticals opportunities...), might have different type and different use of academic sourcing. According to the literature, we however expect here that High Tech sectors such as Pharmaceuticals, Electronics components or equipment, or Aeronautical industries, are more likely to successfully introduce the academic knowledge they grasp from public research organisations.

We have chosen not to include a dummy for government support in our model although the data was available in CIS2. Even if the model may be improved, we are not able to interpret the positive and significant sign of the dummy since some funding is dedicated to knowledge sharing through networking activities with public research organisations (Fonds de la Recherche et de la Technologie, ANVAR, EC fundings... $)^{9}$.

\section{ECONOMETRIC MODEL}

\subsection{Econometric model and issues}

We assumed that the four types of local R\&D commitments define four types of absorptive capacities: A raw absorptive capacity that is induced by the presence of business units that have only non-R\&D activities (production, distribution) in a geographic area. A second absorptive capacity is based on

9 Mohnen et al., (2002) and Adams (2001) introduce the variable that is found significantly positive as we would find it if we introduce it in (1). 
internal R\&D expenditure at the business unit level. Firms, through their local plants are able to absorb local academic knowledge or nearby academic knowledge that is knowledge produced outside the urbanised area the firm is located in but inside the region where the activity is implemented. Thus our basic model can be now written as follows:

$$
\begin{aligned}
A K I_{i}= & \underset{>>0}{\alpha_{u}^{P R O D}} K_{U}^{i, P R O D}+\underset{>0}{\alpha_{u}^{R D}} K_{U}^{i, R D}+\underset{>0}{\alpha_{r}^{P R O D}} K_{R}^{i, P R O D}+\underset{>0}{\alpha_{r}^{R D}} K_{R}^{i, R D}+\underset{>0}{\beta_{1}} R D I N T_{i}+\underset{>0}{\beta_{2}} \operatorname{SBAR} R_{i} \\
& +\underset{>0}{\beta_{3}} R \text { RCenter }_{i}+\underset{>0}{\gamma_{1}} \operatorname{SIZE_{i}}+\underset{<0}{\gamma_{2}} \operatorname{INDEP_{i}}+\underset{<0}{\gamma_{3}} \mathrm{FORGROUP_{i }}+\sum_{m=1}^{14} \delta_{m} I D_{i m}+v_{i}
\end{aligned}
$$

The effective ability to absorb knowledge by firms is expected to be positively and significantly influenced by the academic opportunities available within the urbanised units where the business units are settled. We thus expect $\alpha_{u}^{R D}, \alpha_{r}^{R D}, \alpha_{u}^{P R O D}$ and $\alpha_{r}^{P R O D}$ to be positive.

Beyond the positive expected signs of the parameters underlying the positive influence of the public research organisations surrounding local business units, different assumptions are made in the paper : if absorption is sensitive to the distance of establishments to public research organisation, then the nearest academic R\&D pool will be correlated with the company's AKI, and the nearest academic R\&D knowledge will be larger than that of the distant pool. We thus assumed that $\alpha_{u}^{R D}>\alpha_{r}^{R D}$. The same hierarchy is expected for the other absorptive capacities. Thus we expect also $\alpha_{u}^{P R O D}>\alpha_{r}^{P R O D}$. Assuming that the distant knowledge is harder to absorb, we may impose a downward bias on $\alpha_{u}^{R D}$, $\alpha_{u}^{P R O D}$ due to large cities as Lyon, Marseille or Toulouse, that are not disaggregated into "employment areas".

The local R\&D commitment of a firm is assumed to be more efficient than a simple productive or commercial activity. Similarly, a local R\&D laboratory is assumed to lead a firm to be more effective with the absorption of local academic knowledge. The coefficients are expected to be ordered as follows: $\alpha_{u}^{R D}>\alpha_{u}^{P R O D}$ as well as $\alpha_{r}^{R D}>\alpha_{r}^{P R O D}$.

If the dummy FRGROUP that is 1 when a firm belongs to a French group is taken as a reference, we expect also a weaker ability for tapping academic knowledge for independent firms as well as for foreign subsidiaries $\left(\gamma_{1}<0\right.$ and $\left.\gamma_{2}<0\right)$.

The observed ordered endogenous variable AKI implied a standard ordered logit or probit model. However, an ordered probit model with sample selection is necessary since the ordered explained variable AKI is available only for innovative firms ${ }^{10}$. Thus a first selection part of our econometric model explaining the probability to be an innovative firm is added and specified as follows:

$$
I N N O_{i}=\underset{>0}{\alpha_{u}} K_{U}^{i}+\underset{>0}{\alpha_{r}} K_{R}^{i}+\underset{>0}{\varphi_{1}} \operatorname{SIZE}_{i}+\underset{<0}{\varphi_{2}} \operatorname{INDEP_{i}}+\underset{>0}{\varphi_{3}} \text { FORGROUP }_{i}+\sum_{m}^{14} \delta_{m} I D_{i m}+\varepsilon_{i}(2)
$$

The explanatory variables are the same as in the previous equation except that the stocks of academic knowledge are aggregated: the non-innovative firms have no R\&D expenditure and we thus cannot identify the different kinds of local or regional commitments. However the impact of public research

\footnotetext{
${ }^{10}$ A similar methodology and explained variable is used in Arundel \& Geuna (2001) and in Mohnen et al. (2002). The possible selection bias is taken into account only in Mohnen et al. (2002).
} 
organisations is expected to be positive at the local and regional level of activity. A firm is more likely to innovate if the academic opportunities are high around its different plants or if its plants are settled in regions where public research organisations are important. The local aspect of academic spillovers is considered with the $\alpha_{u}>\alpha_{r}$ hypotheses whereas only innovative foreign subsidiaries are able to compete in their host countries $\left(\varphi_{3}>0\right)$ that is much harder for independent firms that are smaller and do not benefit from intra-group diffusion $\left(\varphi_{2}<0\right)$.

The overall model requires two steps to be estimated. In the first step, we fit the probit model for the innovation variable; a second step then re-estimates the coefficient from the probit model along with the ordered logit coefficients (see Appendix B.). The correlation among the explanatory variables led us to introduce them one by one.

\subsection{Descriptive statistics}

Among the 2339 innovating firms, 54\% declares that academic knowledge (including universities and other government laboratories) is not used at all whereas, $25 \%, 15 \%$ and $6 \%$ declare that academic knowledge is respectively a weak, moderate and strong source of innovation. Is that little? As mentioned by Arundel \& Geuna (2001), if it is low in terms of number of firms, the conclusion is quite different when value added, R\&D spendings and innovation turnover are considered. On the explanatory variables side, more than $50 \%$ of the firms belong to a group. French groups are more frequent (30\%), the foreign manufacturing groups are however numerous (21\%) (See Table 2). Groups are even more frequent when innovative firms or R\&D firms sub-samples are considered, with respectively 65 and $86 \%$ of the observations. The size of firms rises as well as the sample is restricted to innovators and R\&D investors. R\&D intensity is less than $2 \%$ on the innovators sample whereas it reaches almost $4 \%$ on the R\&D sample. Within the last sample, the basic research intensity is about $17 \%$. On average, $83 \%$ of the internal R\&D budget is dedicated to knowledge developments. $30 \%$ of the firms own a R\&D centre (See Table 2). 
Table 1: Descriptive statistics of the sample and sub-samples.

\begin{tabular}{|c|c|c|c|c|}
\hline & Mean & Std.Dev. & Min. & Max. \\
\hline \multicolumn{5}{|l|}{ All observations (4 066) } \\
\hline$K_{U}^{i}$ & $-2,565$ & 3,918 & $-6,908$ & 4,199 \\
\hline$K_{R}^{i}$ & 1,486 & 1,554 & $-6,908$ & 4,028 \\
\hline Log of number of employees & 4,740 & 1,333 & 2,996 & 11,037 \\
\hline Dummy for French group memb. & 0,303 & 0,460 & 0 & 1 \\
\hline Dummy for foreign group memb & 0,211 & 0,408 & 0 & 1 \\
\hline \multicolumn{5}{|l|}{ Innovative firms (2 339) } \\
\hline AKI & 1,713 & 0,908 & 0 & 3 \\
\hline$K_{U}^{i, R D}$ & $-5,380$ & 2,927 & $-6,908$ & 2,930 \\
\hline$K_{U}^{i, P R O D}$ & $-2,668$ & 4,010 & $-6,908$ & 4,199 \\
\hline$K_{R}^{i, R D}$ & $-3,887$ & 4,045 & $-6,908$ & 3,567 \\
\hline$K_{R}^{i, P R O D}$ & 0,316 & 3,406 & $-6,908$ & 3,971 \\
\hline Log of number of employees & 5,205 & 1,419 & 2,996 & 11,037 \\
\hline R\&D /Sales & 0,017 & 0,042 & 0,000 & 0,422 \\
\hline Dummy for French group memb. & 0,367 & 0,482 & 0 & 1 \\
\hline Dummy for foreign group & 0,288 & 0,453 & 0 & 1 \\
\hline \multicolumn{5}{|l|}{ R\&D firms only ( 1009) } \\
\hline$K_{U}^{i, R D}$ & $-3,391$ & 3,569 & $-6,908$ & 2,930 \\
\hline$K_{U}^{i, P R O D}$ & $-2,229$ & 4,178 & $-6,908$ & 4,074 \\
\hline$K_{R}^{i, R D}$ & 0,061 & 3,202 & $-6,908$ & 3,567 \\
\hline$K_{R}^{i, P R O D}$ & $-1,056$ & 4,520 & $-6,908$ & 3,798 \\
\hline Log of number of employees & 6,040 & 1,287 & 2,996 & 11,037 \\
\hline R\&D /Sales & 0,039 & 0,056 & 0,001 & 0,422 \\
\hline R\&D CENTER & 0,305 & 0,461 & 0 & 1 \\
\hline Basic Research / R\&D & 0,172 & 0,260 & 0 & 1 \\
\hline Dummy for French group memb. & 0,482 & 0,500 & 0 & 1 \\
\hline Dummy for foreign group memb. & 0,380 & 0,486 & 0 & 1 \\
\hline
\end{tabular}

( 1 is added to each stock of knowledge before transformation)

Table 2: The weight and polarisation of the largest French urban units with public researchers (scientific fields only).

\begin{tabular}{|c|c|c|c|c|c|}
\hline Geographic bacic units & Rank & $\begin{array}{c}\text { Lab } \\
\text { number }\end{array}$ & $\begin{array}{l}\text { Share of public } R \& D \\
\text { staff within the region }\end{array}$ & $\begin{array}{l}\text { National } \\
\text { share }\end{array}$ & $\begin{array}{l}\text { Equivalent number at } \\
\text { the regional level }\end{array}$ \\
\hline PARIS (urbanised unit) & 1 & 1249 & $99,0 \%$ & $31,2 \%$ & 1,0 \\
\hline PARIS (intra muros) ${ }^{, 1}$ & 1 & 642 & $49,2 \%$ & $15,5 \%$ & 3,5 \\
\hline ORSAY $^{1}$ & 5 & 105 & $16,1 \%$ & $5,1 \%$ & 3,5 \\
\hline $\begin{array}{l}\text { BOULOGNE- } \\
\text { BILLANCOURT }^{1}\end{array}$ & 9 & 173 & $11,2 \%$ & $3,5 \%$ & 3,5 \\
\hline VERSAILLES $^{1}$ & 17 & 92 & $5,8 \%$ & $1,8 \%$ & 3,5 \\
\hline CRETEIL $^{1}$ & 19 & 73 & $4,6 \%$ & $1,4 \%$ & 3,5 \\
\hline VITRY-SUR-SEINE ${ }^{1}$ & 22 & 48 & $3,5 \%$ & $1,1 \%$ & 3,5 \\
\hline SAINT-DENIS $^{1}$ & 26 & 38 & $2,8 \%$ & $0,9 \%$ & 3,5 \\
\hline $\mathrm{EVRY}^{1}$ & 33 & 9 & $1,9 \%$ & $0,6 \%$ & 3,5 \\
\hline MONTREUIL $^{1}$ & 36 & 25 & $1,5 \%$ & $0,5 \%$ & 3,5 \\
\hline
\end{tabular}




\begin{tabular}{lccccc}
\multicolumn{1}{c}{ NANTERRE $^{1}$} & 39 & 16 & $1,3 \%$ & $0,4 \%$ & 3,5 \\
\multicolumn{1}{c}{ CERGY $^{1}$} & 41 & 26 & $1,1 \%$ & $0,4 \%$ & 3,5 \\
LYON $^{\mathbf{b}}$ & 94 & 2 & $0,1 \%$ & $0,0 \%$ & 3,5 \\
TOULOUSE $^{\text {GRENOBLE }}$ & 2 & 206 & $45,7 \%$ & $5,4 \%$ & 2,5 \\
MARSEILLE-AIX $^{\mathbf{b}}$ & 3 & 158 & $97,0 \%$ & $5,4 \%$ & 1,1 \\
MONTPELLIER & 4 & 126 & $44,4 \%$ & $5,3 \%$ & 2,5 \\
LILLE & 6 & 179 & $55,9 \%$ & $4,9 \%$ & 2,4 \\
BORDEAUX & 7 & 222 & $84,4 \%$ & $4,0 \%$ & 1,4 \\
NANCY & 8 & 154 & $80,5 \%$ & $3,9 \%$ & 1,5 \\
STRASBOURG & 10 & 150 & $88,8 \%$ & $3,3 \%$ & 1,3 \\
RENNES & 11 & 86 & $75,3 \%$ & $3,1 \%$ & 1,6 \\
NICE & 12 & 88 & $79,7 \%$ & $3,0 \%$ & 1,5 \\
CLERMONT-FERRAND & 13 & 113 & $66,4 \%$ & $3,0 \%$ & 2,1 \\
NANTES & 14 & 96 & $31,4 \%$ & $2,7 \%$ & 2,4 \\
DIJON & 16 & 85 & $97,7 \%$ & $2,0 \%$ & 1,1 \\
POITIERS & 16 & 80 & $62,1 \%$ & $1,9 \%$ & 2,2 \\
BESANCON & 18 & 62 & $87,6 \%$ & $1,6 \%$ & 1,3 \\
ROUEN & 20 & 38 & $78,9 \%$ & $1,3 \%$ & 1,6 \\
BREST & 21 & 39 & $81,4 \%$ & $1,2 \%$ & 1,4 \\
OTHERS & 23 & 38 & $78,2 \%$ & $1,0 \%$ & 1,6 \\
\hline All & 24 & 69 & $21,2 \%$ & $1,0 \%$ & 2,1 \\
\hline
\end{tabular}

${ }^{1}$ employment area belonging to the same Paris urban unit

Source : Telelab, DEP B3, 1993-1996

${ }^{\mathrm{b}}$ urban unit belonging to the same Rhône-Alpes region

${ }^{c}$ urban unit belonging to the same Provence-Côte d'Azur region

d urban unit belonging to the same Bretagne region

The 4066 CIS2 firms own 15932 business units spread out among 1408 different urbanised units. The 1009 R\&D firms are located in 479 urban units. Table 3 shows that a singular firm runs 3.9 business units at the same time. The business units are usually scattered among almost 3 different urbanised units and two regions. It also shows that $R \& D$ is on average carried out within more than one urban unit $(1,7)$ and more than one region. The table underlines the difficulties to consider innovation within a single urban unit since the process takes place in different cities and regions. Even if $50 \%$ of the firms has only one business unit or plant, $30 \%$ has more than $2.40 \%$ of the firms with more than one unit are settled at least in two different urban units and one third are spread out in two regions or more. $61 \%$ of $R \& D$ firms have settled their $R \& D$ activities within a single urbanised zone. The ratio is similar for mono-regional R\&D firms (66\%) showing that about one third of the firms with $R \& D$ invest in scientific and knowledge activities in several cities and regions. Thus more than 220 innovative firms doing R\&D organise their R\&D activities among three or more French regions.

The French public research organisations with a positive number of employees are 69094 in our database (excluding human and social sciences labs). They are scattered among only 125 urban units. Splitting Paris into different employment areas, we get a final sample of 136 geographic units where public research is settled. Table 3 shows that many regions are monopolar : one urban area is the main location of public research. Paris is a polar case with almost $99 \%$ or the public researchers belonging to the sole urban area (Fontainebleau is the unique urban alternative in the region). Splitting Paris 
urban units into the different employment areas gives a more mitigated view of the first ranked region for public research: the settlement of many universities (e.g. Orsay, Nanterre), public labs from other public research organisations (CNRS, INRA, INRIA) as well as Engineering schools (Polytechnique, Centrale, Ponts et Chaussés).

It leads to a wider equivalent number than on (3.5) suggesting that several public research poles can be identified within the single urban unit Ile de France. In Table 3, the equivalent number ${ }^{11}$ shows that monopoly cities are also Clermont-Ferrand, Toulouse, Dijon, Bordeaux, Besançon, Strasbourg, Montpellier and Poitiers are mainly monopolar ${ }^{12}$. Rouen and Lille are weaker but the second ranked urban areas within their respective regions are far from being equivalent ${ }^{13}$. Bipolar regions are built on the Metz-Nancy, Rennes-Brest, Marseille-Nice couples. Three are almost tripolar regions, RhôneAlpes including important urban areas as Lyon and Grenoble but also second ranked cities as SaintEtienne or Chambery. Nantes is also dominant but next to Angers and Le Mans.

Besides, the CIS2 firms are settled among 1408 urbanised areas whereas public research organisation are present in only 136 areas, $60 \%$ of the firms succeed however to be settled in an urban unit where a public research organisation is settled. The rate rise to $67 \%$ and $82 \%$ for innovative firms and firms with $R \& D$ departments. On the last set of firms with R\&D departments, $65 \%$ carry out $R \& D$ at least in one area where a public research organisation is settled.

\section{ECONOMETRIC RESULTS}

We first comment our results on the selection part of the model. We thus tackle the ordered probit equation.

We first estimate the selection model without knowledge stocks. Even though the different stocks of knowledge are linked with the number of business units and the size of a firm, we expect to show the positive impact of the level of external academic knowledge on the ability of a firm to use it in the innovation process. Table 4 gives three different estimations. In all three models ((Eq31) to (Eq33)), the importance of academic sourcing rises significantly with the size of firms. As expected, French

11 The equivalent number is the inverse of the Herfindhal concentration index based on the share $\mathrm{S}$ of the different urban areas $\mathrm{u}$ within a region $\mathrm{r}(\mathrm{r}=1, . ., 22)$ that EquivNumb $b_{r}=1 / \sum_{u}\left(S_{u}^{r} / \sum_{\substack{u \\ u \subset r}} S_{u}^{r}\right)^{2}$. For each region $\mathrm{r}(\mathrm{r}=1, . ., 22)$, it gives the theoretical number or urban areas that there would be if all the urban areas had the same share in a same region. Here we neglect the share of rural locations. The minimum is then 1 if there is a single location urban area with a region.

12 The following regions Corse, Champagne-Ardennes, Limousin, Normandie and Picardie, do not have a single urban area with more than 1000 researcher (excluding overseas regions). All the regions are monopolar with the respective urban areas of Corte, Reims, Limoges, Caen, and Amiens.

13 In the Lille region, the urban areas of Valencienne, Douai, Arras, Calais, Boulogne Dunkerque, Béthune also have a public research staff. Rouen, Le Havre are the main places where public research is located in the Haute Normandie Region. 
and foreign subsidiaries are more likely to innovate than independent firms. Moreover, foreign affiliates are even more able to innovate than native affiliates ${ }^{14}$, all the other remaining equal.

For a given local settlement of the different business units, a firm is more likely to be an innovator when the level of academic knowledge rises. Separating the effect of academic sourcing between distances, Table 5 suggests that both stocks of knowledge have a positive and significant impact on the likelihood to be an innovator $((\mathrm{Eq} 32) \text { and }(\mathrm{Eq} 33))^{\circ}$. The second interpretation is that the location is endogenous. In this case, a firm would be more likely to innovate when it settles its different business units in the same city or region as the largest public research organisations. However, the magnitude is found much lower than the size or group effect. The correlation between the two variables lead to changes in the coefficients and standard errors when they are simultaneously introduced (Eq31). The comparison of marginal effects suggests however that the likelihood to be an innovator would relies more on a rise of public research in the regional belt than in the same urbanised unit ${ }^{15}$. Thus, even if we succeed in introducing the (positive) effect of academic knowledge in the selection process, the expected 'proximity' effect is not found as in many European studies (See Feldman, 1998).

Table 3: Selection equation: probability to be innovative.

\begin{tabular}{lccc}
\hline & $(\mathrm{Eq} 31)$ & $(\mathrm{Eq} 32)$ & $(\mathrm{Eq} 33)$ \\
\hline $\mathrm{K}_{\mathrm{U}}$ & 0,009 & $0,015^{* *}$ & \\
& $(1,421)$ & $(2,403)$ & \\
& $0,045^{* * *}$ & & $0,052^{* * *}$ \\
$\mathrm{~K}_{\mathrm{R}}$ & $(2,806)$ & & $(3,416)$ \\
& $0,393^{* * *}$ & $0,402^{* * *}$ & $0,397^{* * *}$ \\
Log of number of employees & $(15,186)$ & $(15,609)$ & $(15,429)$ \\
& $-0,112^{*}$ & $-0,112^{*}$ & $-0,119^{* *}$ \\
Dummy for Independent firms & $-(1,863)$ & $-(1,877)$ & $-(1,989)$ \\
& $0,135^{*}$ & $0,147^{* *}$ & $0,137^{*}$ \\
Dummy for foreign group memb & $(1,922)$ & $(2,102)$ & $(1,951)$ \\
\hline
\end{tabular}

4066 observations, and 2339 innovators selected.

Each selection equation is estimated within a global FIML procedure including the ordered logit part.

The selection equations reported includes the same right hand side variables than the not reported ordered probit equation.

*** significant at the 1 percent level. ** Significant at the 5 percent level. * Significant at the 10 percent level.

The estimates of the ordered probit model are presented in Table 5. The same positive parameter is found as expected when the size of innovating firms is considered. It confirms that large firms are better at academic sourcing than small ones. A set of size dummies is introduced to check if there is a possible $U$ shape on the explanatory variable: the parameters of the dummies are significant, positive,

14 The computed marginal effects suggest that the impact is twice for foreign groups ( $9 \%$ instead of $4 \%$ ) whereas a $1 \%$ increase in size rises the probability of innovating by $15 \%$.

15 A $1 \%$ increase in local and regional academic knowledge respectively rises the probability to innovate by $0.6 \%$ and $2 \%$ in (Eq32) and (Eq33) or, improperly, by a $0.3 \%$ and $1.7 \%$ in (Eq31). 
increasing and ordered. The results give support to the results obtained on the number of employees taken in logarithm.

As previously the effect of belonging to a group is positive even if the effect is restricted to native groups. As expected, the effect is negative for foreign groups that are, like independent firm, less able to value academic knowledge in their innovation process (see (Eq41) for example).

The various models confirm also that $R \& D$ intensity is increasing the ability to benefit from academic research. For a given size and industry, firms with larger research projects are thus more able to include academic knowledge in their innovation process. The intensity of upstream research (basic and applied) is found positive as the effect of the Center variable on the probability to benefit from public research organisations. The results confirm the expectations based on the empirical and theoretical literature $^{16}$. The analysis of the marginal effects shows that a one percent rise in R\&D intensity increases by $28 \%$ the probability of considering the public research organisations as "important" for innovation. The impact is also important regarding the share of basic \& applied research: a point increase rises the same probability by $3,3 \%$. Similarly, to run a R\&D centre or to belong to a French group increases the probability of considering academic sourcing as "important" by $1,0-1,3 \%$ compared to a foreign affiliate.

Table 4: The ordered probit equation using raw stocks of public knowledge $(\mathrm{w}=1)$.

\begin{tabular}{|c|c|c|c|c|c|}
\hline & (Eq41) & (Eq42) & (Eq43) & (Eq44) & $(\mathrm{Eq} 45)$ \\
\hline $\mathrm{K}_{\mathrm{U}}^{\mathrm{RD}}$ & $\begin{array}{c}-0,006 \\
(-0,286)\end{array}$ & $\begin{array}{l}0,013^{* *} \\
(2,508)\end{array}$ & & & \\
\hline $\mathrm{K}_{\mathrm{U}}^{\mathrm{PROD}}$ & $\begin{array}{c}-0,003 \\
(-0,821)\end{array}$ & & $\begin{array}{c}-0,005 \\
(-1,453)\end{array}$ & & \\
\hline $\mathrm{K}_{\mathrm{R}}^{\mathrm{RD}}$ & $\begin{array}{l}0,016 \\
(0,790)\end{array}$ & & & $\begin{array}{l}0,012 * * * \\
(2,676)\end{array}$ & \\
\hline $\mathrm{K}_{\mathrm{R}}^{\mathrm{PROD}}$ & $\begin{array}{l}-0,004 \\
(-0,606)\end{array}$ & & & & $\begin{array}{l}-0,013 * * \\
(-2,218)\end{array}$ \\
\hline Log of number of employees & $\begin{array}{l}0,180^{* * *} \\
(2,860)\end{array}$ & $\begin{array}{l}0,173 * * * \\
(2,773)\end{array}$ & $\begin{array}{l}0,193 * * * \\
(3,102)\end{array}$ & $\begin{array}{l}0,172 * * * \\
(2,766)\end{array}$ & $\begin{array}{l}0,192 * * * \\
(3,096)\end{array}$ \\
\hline R\&D / Sales & $\begin{array}{l}2,988 * * * \\
(4,367)\end{array}$ & $\begin{array}{l}3,104 * * * \\
(4,536)\end{array}$ & $\begin{array}{l}3,512 * * * \\
(5,444)\end{array}$ & $\begin{array}{l}3,082 * * * \\
(4,537)\end{array}$ & $\begin{array}{l}3,258^{* * *} \\
(4,914)\end{array}$ \\
\hline Basic \& Applied Research / R\&D & $\begin{array}{l}0,439^{* * *} \\
(2,905)\end{array}$ & $\begin{array}{l}0,423^{* * *} \\
(2,830)\end{array}$ & $\begin{array}{l}0,490^{* * *} \\
(3,325)\end{array}$ & $\begin{array}{l}0,422^{* * *} \\
(2,817)\end{array}$ & $\begin{array}{l}0,486^{* * *} \\
(3,301)\end{array}$ \\
\hline R\&D center & $\begin{array}{l}0,155^{* *} \\
(2,044)\end{array}$ & $\begin{array}{l}0,167^{* *} \\
(2,239)\end{array}$ & $\begin{array}{l}0,191 * * \\
(2,536)\end{array}$ & $\begin{array}{l}0,165^{* *} \\
(2,207)\end{array}$ & $\begin{array}{l}0,174 * * \\
(2,312)\end{array}$ \\
\hline Dummy for independent firm. & $\begin{array}{l}-0,179 * * \\
(-2,181)\end{array}$ & $\begin{array}{l}-0,176^{* *} \\
(-2,163)\end{array}$ & $\begin{array}{l}-0,177 * * \\
(-2,169)\end{array}$ & $\begin{array}{l}-0,178 * * \\
(-2,181)\end{array}$ & $\begin{array}{l}-0,173 * * \\
(-2,119)\end{array}$ \\
\hline Dummy for foreign group memb. & $\begin{array}{r}-0,110^{*} \\
(-1,713) \\
\end{array}$ & $\begin{array}{r}-0,112^{*} \\
(-1,748) \\
\end{array}$ & $\begin{array}{r}-0,106^{*} \\
(-1,658) \\
\end{array}$ & $\begin{array}{r}-0,114^{*} \\
(-1,767) \\
\end{array}$ & $\begin{array}{r}-0,108^{*} \\
(-1,683) \\
\end{array}$ \\
\hline$\rho$ & $\begin{array}{c}-0,034 \\
(-0,104)\end{array}$ & $\begin{array}{c}-0,023 \\
(-0,072)\end{array}$ & $\begin{array}{c}-0,037 \\
(-0,113)\end{array}$ & $\begin{array}{c}-0,021 \\
(-0,065)\end{array}$ & $\begin{array}{c}-0,033 \\
(-0,102)\end{array}$ \\
\hline $\log L$ & $-4610,1$ & $-4611,6$ & $-4614,0$ & $-4611,2$ & $-4612,5$ \\
\hline
\end{tabular}

\footnotetext{
${ }^{16}$ Following Cassiman et al. (2002), instead of industry dummies, we introduce the Herfindhal concentration index as a measure of the size of the market (in a Sutton's spirit in a nutshell). The effect has the right sign but is hardly significant. It is also found to be much less powerful than a set of industry dummies that also includes appropriation regimes that cannot be taken into account explicitly in our specification.
} 
4066 observations, and 2339 innovators selected

All equation include a selection part including $\mathrm{K}_{\mathrm{U}}$ and $\mathrm{K}_{\mathrm{R}}$. The selection parts are not reproduced here.

The 14 industry dummies are always included. Nor the estimated parameters of the industry dummies, neither the threshold parameters $\mu$ are reported. The reference is to belong to a French group.

The parameter are calculated at the sample mean.

*** significant at the 1 percent level. ** Significant at the 5 percent level. * Significant at the 10 percent level.

Last, the introduction of industry dummies shows the sectors that are, ceteris paribus, more likely to be science based innovators: thanks to the computation of marginal effects Pharmaceuticals, Ship building, aeronautics and train are the most science based innovators while Chemicals, Mechanical equipment, bulk materials or even basic metals and fabricated metal products claim that academic sourcing has a significant higher effect on their innovation process than firms from other industries. Compared to the Pavitt's classification (1984), the current French science based industry thus does not include Electrical and electronic components and equipment but integrate specialised suppliers as machinery or even scale intensive as bulk materials. Even if similar results (except for Electronic components and equipment) can be found in Cohen et al. (2002), our results are to be confirmed since we do not take into account the different possible academic fields surrounding the various establishments.

The higher the local academic knowledge is in urban units where a firm carries out $R \& D$, the higher the effects of academic sourcing are important (Eq 42). A positive and significant effect is found when the stock of academic knowledge is considered where R\&D investments are done (Eq 44). Multicollinearity between variables limits the ability to identify sharply the magnitude of the two effects even if comparison effects between (Eq42) and (Eq44) suggest that regional knowledge matters similarly than local academic knowledge even if the magnitude are very small compared to other explanatory variables ${ }^{17}$. For a given level of public research, to develop R\&D activities near public labs significantly improve the impact of academic sourcing. The same conclusion is also found when regional stocks are considered: to settle within an urban unit will also increase the ability to catch academic knowledge located in other places within the same region. The results also suggest that firms are bounded when they have to locate their R\&D activities: they can choose a city in order to benefit from public labs but also, to choose a given city to rather access the whole knowledge that are available within the same region.

When introduced one by one in our model, academic knowledge available through non-R\&D activities (commercial, production, management) is both found negatively correlated but significant only at the regional level only ((Eq43) vs (Eq45)). The introduction of both stocks at the urban level suggests that the impact of academic sourcing increases when public researchers are surrounded by R\&D staffs rather than productive or commercial employees ${ }^{18}$. The result holds also at the regional level ${ }^{19}$. The result is consistent with the idea that firms' absorptive capacities rely also on the repartition of $R \& D$ activities among business units. It suggests that firms should invest in R\&D in regions where they want to benefit from scientific opportunities led by PROs. A firm would therefore not be able to boost its absorptive capacity if it settles its production, sales or management activities in areas with high

\footnotetext{
$170,1 \%$ for both.

18 The equality between the two coefficient of the two stocks at the urban level is rejected at the $1 \%$ level with a Wald value of 7.81 .

19 Wald is $7.70 * * *$
} 
public research organisations. Corollary, when the question of academic sourcing is dealt with, it should be avoided to set up their non-R\&D activities away from their R\&D activities.

The interpretation for firms without R\&D is more puzzling: even if they cannot capture academic knowledge through $R \& D$ employees, they may worry about their competitors with $R \& D$ that are able to absorb knowledge. The negative effect would be thus a relative effect, a loss in their relative efficiency in their absorptive activities. This result concerns however only one dimension of a location decision. Other variables as higher wages or public research organisations overwhelmed by private offers would mitigate such a polarisation effect. As mentioned, the various significant effects vanish when the whole set of academic knowledge variables is considered (Eq 41). The multicollinearity does not allow us to get the right values for the four parameters and standard errors. A Wald test suggests however that the introduction of the four stocks significantly improves the model (Critical value is 9.42 , thus the nullity is rejected at the $10 \%$ level). The correlation coefficient between error terms $(\rho)$ is never significant. The impact of academic sourcing is thus not biased by a selection effect. The results do not rely on the sole characteristics of the observed innovators.

\section{CONCLUSION}

The first results presented in the paper do confirm most of the hypothesis introduced at the beginning of the paper even if the geographic boundaries of academic spillovers are not found. What are the implications of these results for policy makers? The results are not only to be interpreted by firms but by policy makers. Instead of endogenous settlement of business units and especially business units with R\&D activities, the impact on academic sourcing can be interpreted as an influence of the endogenous level of public researchers at the local level. In this case, the results suggest that an increase by government of the number of researchers within cities will have (small) positive effects on the relevance of academic sourcing by local firms. But it also suggests that the effect is restricted on geographic areas where firms do R\&D. Furthermore, the results suggest that a government deciding to increase the number of employees in cities or regions where a firm is present but does not undertake any $\mathrm{R} \& \mathrm{D}$, will be rather considered negatively by innovators. To boost public research organisations in areas where firms only produce would not induce an efficient academic sourcing for firms. The first result thus speaks rather for a comprehensive local development that involves at the same time private $R \& D$ and public research. The result also suggest that regional policies have to fight against a polarisation of R\&D capabilities by firms that would like to be able to benefit from outputs of public research organisations: If one trust that such sourcing will be more and more at the core of the future so called knowledge society, regions with a large number of researchers working in public organisations will be more and more attractive and the catching up of less favoured regions will be difficult. The gap therefore justifies that local co-ordination policies have to be specific for the last kind of industries. Intermediate regions with large public units and low industrial R\&D (As Languedoc-Roussillon or Alsace in France) should be targeted with specific support to industrial R\&D in order to balance the local absorptive mechanisms and benefit from their high scientific opportunities. Of course, our empirical investigation does not concern all countries and only holds for France where private and public R\&D are very concentrated. Further more, the small magnitude of the effects may rely on the aggregated fields. The point leads us to considered future possible investigations. 
The new empirical method implemented to deal with academic sourcing has several weaknesses. A first limitation is a poor treatment of the group dimensions. Even if we had considered the location as an endogenous variable for a firm, it would be more adequate to consider it at the level of the group. Undirect academic sourcing through affiliates and especially affiliated R\&D labs, even yet considered in the model through the group dummies, should mitigate the requirement to locate business units near public research organisations or even to invest in R\&D. An interesting and easier investigation on MNCs behaviour would be to consider more precisely the advantage of native groups. Identifying the nationality of foreign firms settled in France, we should analyze if there is a European, non-European effect where US or Japanese affiliates would be weaker at sourcing French PROs. A second aspect would be where to locate private R\&D centers. The question is introduced in the recent French annual questionnaire on business R\&D. However this new data cannot match the location of public research organisation since the French ministry of research stopped the Telelab survey in 1998. A third boundary is the lack of variables dealing with competition between local business units to grasp a limited set of academic knowledge. Such an indicator would be able to compute at the urban level. In our framework however, it would require to locate at the urban unit level, all the business units of the manufacturing industries, about 46000 , instead of the burdening 15932 units we yet considered in the CIS2 sample... The new empirical methodology sustained in the paper is however broad enough to deal with other aspects of academic sourcing. One major follow up would be to address the question of proximity between science and industry dividing by scientific fields the stocks of knowledge. A complementary topic would be to deal with the effect of specialisation of academic production on the innovation process.

\section{REFERENCES}

ACS, Z.J., AUDRETSCH D., 1990. Innovation and Small Firms, Boston, MIT Press.

ADAMS, J.D., 1990. Fundamental Stocks of Knowledge and Productivity Growth, Journal of Political Economy, Vol. 98, n 4, pp. 673-702.

ADAMS, J.D., 2001. Endogenous R\&D Spillovers and Industrial Research Productivity, WP, July, $38 \mathrm{p}$.

ADAMS, J.D., JAFFE, A., 1986. Bounding the effects of R\&D, an investigation using matched establishment firm data, RAND Journal of Economics, 27, pp. 700-721.

Agrawal, A., Henderson, R., 2002. Putting patents in context, Exploring knowledge transfer from MIT, Management Science, January, Volume, 48, N 1, pp. 44-60.

Almeida, P., Kogut, B., 1997. The exploration of technological diversity and the geographic localization of innovation, Small Business Economics, n ${ }^{\circ}$, pp. 21-31.

ARORA, A., GAMBARDElla, A., 1994. Evaluating Technological Information and Utilising it, Journal of Economic Behaviour and Organisation, 24, pp. 91-114.

Arundel, A., GeunA, A., 2001. Does Proximity Matter for Knowledge Transfer from Public Institutes and Universities to Firms? WP, SPRU, University of Sussex, October. 
Audretsch, D., Feldman, M, 1996. R\&D spillovers and the geography of innovation and production, The American Economic Review, vol. 86, n 3, juin, pp. 630-640.

Audretsch, D., Feldman, M., 1996. "R\&D Spillovers and the Geography of Innovation and Production", American Economic Review, 86, 4, pp. 253-273.

AudRETSCH, D., FeldMAN, M., 1999. Innovation in cities, science-based diversity, specialization and localized competition, European Economic Review, n43, pp. 409-429.

Audretsch, D., StePhan, P., 1996. Company-scientist locational links, the case of biotechnology. American Economic Review, 805, 83, pp. 641-652.

Beise, M., Stahl, H., 1999. Public research and industrial innovations in Germany, Research Policy, n'28, pp. 397-422.

BRESCHI, S., LisSONI, F., 2001. Knowledge spillovers and local innovation systems, a critical survey, Liuc paper $\mathrm{N}^{\circ} 84$, March.

Cassiman, B., Perez-Castrillo D., Veugelers, R., 2001. Endogeneizing know-how flows through the nature of R\&D investments, International Journal of Industrial Organization, Volume 20, Issue 6, 01, June, pp. 775-799.

COCKBURn, I., HENDERSON, R., 1998. Absorptive capacity, co-authoring behaviour, and the organization of Research in drug discovery, The Journal of Industrial Economics, Volume 46, Issue 2, June, pp. 157-182.

Cockburn, I., Henderson, R., Stern, S., 1999. Balancing Incentives, The Tension Between Basic and Applied Research, NBER Working Paper, W6882, January.

Cohen, W.M., Levinthal, D.A. 1989. Innovation and Learning, The Two Faces of R\&D, The Economic Journal, Vol. 99, n 3, September, pp. 569-596.

Cohen, W.M., Nelson, R.R., WALSh, J.P., 2002. Links and Impacts, The Influence of Public Research on Industrial R\&D, Management Science, Vol.48, No.1, January 2002. pp. 1-23.

Feldman, M, 1994. Knowledge complementarity and innovation, Small Business Economics, $\mathrm{n}^{\circ}$ 6, pp. 363-372.

FELDMAN, M. P., 1999. The New Economics of Innovation, Spillovers and Agglomeration, A Review of Empirical Studies, Economics of Innovation and New Technology, 8, pp. 5-25.

FuJITA M., THISSE J.F., 2002, Economics of Agglomeration; Cities, Industrial Location and Regional Growth, Cambridge University Press, Cambridge.

GLAESER, E., 1999. Learning in Cities, Journal of Urban Economics, 46, pp. 254-277.

Granstrand, O., HAKANSON, L., SJOLANDER, S., 1993. Internationzation of R\&D, A survey of some recent research, Research Policy, 22, 5/6, pp. 413-430. 
GREEN, W.H., 2000. Econometric Analysis, $4^{\text {th }}$ edition, Prentice-Hall Inc., New Jersey.

GRILICHES, Z., 1990. Patent statistics as economic indicators, A survey, Journal of Economic Litterature, Vol. 28, pp. 1661-1707.

HÅKANSON, L., NOBEL, R., 1993.. Foreign research and development in Swedish multinationals. Research Policy, 22, pp. 373-396.

Hansen, T.M., 1999. The Search-Transfer Problem, The Role of Weak Ties in Sharing Knowledge across Organization Subunits, Administrative Science Quarterly, 44, pp. 82-111.

HENDERSON, R., COCKBURN, I., 1996. "Scale, scope, and spillovers, the determinants of research productivity in drug discovery", The RAND Journal of Economics, 271, pp. 32-59.

JAFFE, A.B., 1986, Technological Opportunity and Spillovers of R\&D, Evidence from Firms, Patents, Profits and Market Value, American Economic Review, 76, pp. 984-1001.

JAFFE, A.B., 1989, Real effects of academic research, The American Economic Review, vol 79, $\mathrm{n}^{\circ}$ 5, décembre, pp. 957-970.

Jaffe, A.B., Trajtenberg, M., Henderson R. 1993., Geographic localization of knowledge spillovers as evidenced by patent citations, The Quaterly Journal of Economics, août, pp. 577598.

KusunOKI, K., NONAKA, I., NAGATA, A., 1998. Organizational Capabilities in Product Development of Japanese Firms, A Conceptual Framework and Empirical Findings, Organization Science, Vol. 9, Nº, November-December, pp. 699-718.

LE BAS, C., Zuscovitch, E., 1993. Apprentissage technologique et organisation, Economies et Sociétés, Série Dynamique technologique et organisation, vol. 1, N 5, pp. 153-195.

LIM, K., 2000. "The Many Faces of Absorptive Capacity, Spillovers of Copper Interconnect Technology for Semiconductor Chips", Faculty of Business Administration National University of Singapore, Working paper, September, 65 p.

LIM, K., 2001. The Relationship between Research and Innovation in the Semiconductor and Pharmaceutical Industries (1981-97), WP, National University of Singapore, 20 October, 62 p.

MANSFIELD, E., 1991. Academic Research and Industrial Innovation, Research Policy, Vol. 20, $\mathrm{n}^{\circ}$ 1, Feb., pp. 1-12.

MANSFIELD, E., 1995. Academic research underlying industrial innovations, sources, characteristics, and financing, The Review of Economics and Statistics, vol LXXVII, ${ }^{\circ}$ 1, February, pp. 55-65.

MANSFIELD, E., LEE, J.Y., 1996. The modern University, contributor to industrial innovation and recipient of industrial R\&D support, Research Policy, n 25, pp. 1047-1058.

Mohnen, P., HoAREAU, C., 2002. What types of enterprise forges close links with universities and government labs? Evidence from CIS2, WP, CIRANO \& MERIT, January. 
NIOSI, J., 1999. The Internationalization of Industrial R\&D, From Technology Transfer to the Learning Organization, Research-Policy, 28 (2-3), March, pp. 107-17.

PAVITT, K., 1991. What makes basic research economically useful?, Research Policy (20)2, pp. 109119.

PAVITT, K., 1984. Sectoral Patterns of Technological Change; Toward a Taxonomy and a Theory, Research Policy, Vol. 13, pp. 343-373.

Rosenberg, N., 1990. Why do Firms Do Basic Research (With their Own money)?, Research Policy, Vol. 19, n², pp. 165-174.

StiglitZ, J.E., 1987. Learning to Learn, Localized Learning and Technological Progress, in Dasgupta, P. \& Stoneman, P. (eds), Technology Policy and Economic Performance, Cambridge University Press, pp. 125-154.

Veugelers, R., 1997. Internal R\&D expenditures and External Technology Sourcing, Research Policy, 26, 3, pp. 303-316.

VINCENTI, W.G., 1993. What engineers know and how they know it, analytical studies from aeronautical history, John Hopkins University Press.

Von Zedtwitz, M., Gassmann, O., 2002. Market versus technology drive in R\&D internationalization, four different patterns of managing research and development, Research Policy, (31)4, pp. 569-588.

ZUCKer, L.G., DARBY, M.R., Brewer, M.B., 1998. Intellectual Human Capital and the Birth of U.S. Biotechnology Enterprises, American Economic Review, 88, March , pp. 290-306. 


\section{Appendix A: Variables construction}

The national stock of academic knowledge $K_{F R A N C E}^{i}$ available for a firm $i$ is the sum of the number of the various labour forces involved in public research organisations such as researchers, teacherresearchers, $\mathrm{PhD}$ students, invited researchers or teachers, and research technicians. The stock is computed using different weights depending on the time dedicated to the production of knowledge. The entire bulk of researchers and $\mathrm{PhD}$ students are taken, whereas half of researcher-teachers, technicians and invited researchers or teachers are added. Once computed for each geographic units, $K_{F R A N C E}^{i}$ can be shared into three stocks reflecting three geographic circles around business units : the urban stock, $K_{U}^{i}$, the regional belt $K_{R}^{i}$ and the national belt stocks $K_{0}^{i}$. We thus have $K_{\text {FRANCE }}^{i}=K_{U}^{i}+K_{R}^{i}+K_{0}^{i}=69094$ where $K_{0}^{i}$ is a residual stock of public knowledge available in geographic areas where a firm $i$ has no business unit. The sum of the three stocks is a constant and thus cannot be introduced into our model for perfect multicollinearity reasons. The stock $K_{U}^{i}$ at the urban area level, leads to two different kinds of local stocks of academic knowledge, summing all different fields of knowledge $(\mathrm{j}=1, . ., 31)$ possibly available for a firm $\mathrm{i}$ are:

$$
\left\{\begin{aligned}
K_{U}^{i} & =K_{U}^{i, P R O D}+K_{U}^{i, R D} \text { when } P R O D_{u}^{i}=1 \text { or } \operatorname{IRD}_{u}^{i}=1 \\
K_{U}^{i, P R O D} & =\sum_{u=1}^{u=1389} \sum_{j=1}^{j=31} w_{u}^{i} K_{u j}^{i} \quad \text { when } P R O D_{u}^{i}=1 \text { and } \operatorname{IRD}_{u}^{i}=0 \\
K_{U}^{i, R D} & =\sum_{u=1}^{u=1389} \sum_{j=1}^{j=31} w_{u}^{i} K_{u j}^{i} \quad \text { when } P R O D_{u}^{i} \geq 0 \text { and } \operatorname{IRD}_{u}^{i}=1 \\
w_{u}^{i} & =\frac{n_{u}^{i}}{n^{i}}
\end{aligned}\right.
$$

Where, $P R O D_{u}^{i}$ 's value is 1 when a firm i has at least one establishment without R\&D execution in the $u$ urban area and 0 if not; $I R D_{u}^{i}$ is 1 when a firm $i$ has at least one establishment executing $R \& D$ in the $u$ urban area, 0 if not. $w_{u}^{i}=1$ when the raw urban stock of academic knowledge is given to the business units whatever is their size. $w_{u}^{i}=\frac{n_{u}}{n^{i}}$ when the mean of urban stocks of knowledge is weighted by the share of employees located within the considered urban unit.

The stock $K_{R}^{i}$ is computed at the regional level, and gives a measurement of the academic knowledge surrounding urban areas where business units are settled. It leads us to a similar calculation :

$$
\left\{\begin{aligned}
K_{R}^{i} & =K_{R}^{i, P R O D}+K_{R}^{i, R D} \quad \text { when } P_{R O D_{r}^{i}=1 \text { or } \operatorname{IRD}_{r}^{i}=1} \\
K_{R}^{i, P R O D} & =\sum_{r=1}^{r=22} \sum_{j=1}^{j=31} w_{r}^{i} K_{r j}^{i}-K_{U}^{i, P R O D} \text { when } P R O D_{r}^{i}=1 \text { and } \operatorname{IRD}_{r}^{i}=0 \\
K_{R}^{i, R D} & =\sum_{r=1}^{r=22} \sum_{j=1}^{j=31} w_{r}^{i} K_{r j}^{i}-K_{U}^{i, R D} \quad \text { when } \operatorname{PROD}_{r}^{i} \geq 0 \text { and } \operatorname{IRD}_{r}^{i}=1 \\
w_{r}^{i} & =\frac{n_{r}^{i}}{n^{i}}
\end{aligned}\right.
$$

Where, $P R O D_{r}^{i}$,s value is 1 when a firm $i$ has at least one establishment without R\&D execution in the region $(\mathrm{r}=1, . ., 22)$ and 0 if not; $I R D_{r}^{i}$ is 1 when a firm $i$ has at least one establishment executing $\mathrm{R} \& \mathrm{D}$ in the $\mathrm{r}$ regions, 0 if not. $w_{r}^{i}=1$ when the raw regional stock of academic knowledge is given to 
the business units whatever is their size. $w_{r}^{i}=\frac{n_{r}^{i}}{n^{i}}$ when the mean of regional stocks of knowledge is weighted by the share of employees located within the considered regional belt.

0.001 is added to all academic knowledge stocks that are also divided by 1000 . Thus the six different variables are taken in logarithm. 


\section{Appendix B. Econometric issues}

The econometric model is an ordered probit model with sample selection. It includes two parts as follow:

$$
\left\{\begin{array}{l}
\operatorname{INNO}_{i}^{*}=\alpha Z_{i}+\varepsilon_{i} \\
\operatorname{INNO}_{i}=1 \text { if } \text { INNO }_{i}^{*}>0 \\
\operatorname{INNO}_{i}=0 \text { if } \operatorname{INNO}_{i}^{*}=0 \\
\text { and } \\
A K I_{i}^{*}=\beta X_{i}+v_{i} \\
A K I_{i}=0 \text { if } \quad A K I_{i}^{*} \leq \mu_{0} \text { and } \operatorname{INNO}_{i}=1 \\
A K I_{i}=1 \text { if } \mu_{0}<A K I_{i}^{*} \leq \mu_{1} \text { and } \operatorname{INNO}_{i}=1 \\
A K I_{i}=2 \text { if } \mu_{1} \leq A K I_{i}^{*} \leq \mu_{2} \text { and } \operatorname{INNO}_{i}=1 \\
A K I_{i}=3 \text { if } \quad \mathrm{AKI}_{i}^{*}>\mu_{2} \text { and } \operatorname{INNO}_{i}=1
\end{array}\right.
$$

where error random terms $v$ and $\varepsilon$ are assumed to be independently and identically jointly distributed.

INNO* is a latent variable measuring the level of innovation. The variable is not observed but there is an observed counterpart to INNO* is the dichotomous variable INNO that equals 1 when a firm $i$ declares to be a product or process innovator, including firms with non achieved innovation projects or innovation failure (that is INNO* $>0$ ), and INNO equals 0 otherwise. $Z_{\mathrm{i}}$ is the matrix of explanatory variables (see equation (2)) and $\alpha$ the set of coefficients to be estimated. The second side of the model is built around a second latent regression AKI* that is the unobserved estimation of the impact of academic knowledge on the private innovation process. The observed counterpart to $\mathrm{AKI}_{\mathrm{i}}{ }^{*}$ is the defined polychotomous AKI variable. $X_{\mathrm{i}}$ is a matrix of explanatory variables defined in equation (1) and $\beta$ the set of coefficients to be estimated.

To take into account the selection possible bias, the kind of model requires two steps to be estimated. In the first, we fit a probit model for the selection variable, INNO. The second step re-estimates the coefficient $\alpha$ from the probit model along with $\beta$ and $\mu$, obtaining a FIML set of estimates for all parameters including $\rho^{20}$.

$20\left(\varepsilon_{\mathrm{i}}, v_{\mathrm{i}}\right) \sim>\mathrm{N}^{2}[0,0,1,1, \rho]$, that is independently and identically distributed according to a bivariate normal distribution with mean 0 , variance 1 and covariance $\rho$. See Green (2000) for further econometric precision. 